OPEN ACCESS

Edited by:

Colin Roger MacKenzie,

National Research Council Canada (NRC-CNRC), Canada

Reviewed by:

Andrew Hayhurst,

Texas Biomedical Research Institute,

United States

Serge Muyldermans,

Vrije Universiteit Brussel, Belgium

*Correspondence:

Tianlei Ying

tlying@fudan.edu.cn

Specialty section:

This article was submitted to

Vaccines and Molecular

Therapeutics,

a section of the journal

Frontiers in Immunology

Received: 01 September 2017

Accepted: 30 November 2017

Published: 13 December 2017

Citation:

Wu Y, Jiang S and Ying T (2017)

Single-Domain Antibodies

As Therapeutics against Human

Viral Diseases.

Front. Immunol. 8:1802.

doi: 10.3389/fimmu.2017.01802

\section{Single-Domain Antibodies As Therapeutics against Human Viral Diseases}

\author{
Yanling Wu, Shibo Jiang and Tianlei Ying* \\ Key Laboratory of Medical Molecular Virology of Ministries of Education and Health, School of Basic Medical Sciences, \\ Fudan University, Shanghai, China
}

In full-size formats, monoclonal antibodies have been highly successful as therapeutics against cancer and immune diseases. However, their large size leads to inaccessibility of some epitopes and relatively high production costs. As an alternative, single-domain antibodies (sdAbs) offer special advantages compared to full-size antibodies, including smaller size, larger number of accessible epitopes, relatively low production costs and improved robustness. Currently, sdAbs are being developed against a number of viruses, including human immunodeficiency virus-1 (HIV-1), influenza viruses, hepatitis $\mathrm{C}$ virus (HCV), respiratory syncytial virus (RSV), and enteric viruses. Although sdAbs are very potent inhibitors of viral infections, no sdAbs have been approved for clinical use against virial infection or any other diseases. In this review, we discuss the current state of research on sdAbs against viruses and their potential as therapeutics against human viral diseases.

Keywords: single-domain antibody, nanobody, viral disease, antiviral therapeutics, human immunodeficiency virus-1

\section{INTRODUCTION}

Antibody-based therapeutics are enjoying significant clinical success, with over 70 such molecules approved by the US FDA and hundreds more in various phases of clinical trials (1). Notably, although antibodies have been proven to be effective against a number of diseases, most FDA-approved monoclonal antibodies (mAbs) are used to treat cancer and immune disorders $(1,2)$, and only one antiviral humanized $\mathrm{mAb}$, palivizumab, has been approved as a prophylactic to prevent respiratory syncytial virus (RSV) infection in neonates and immunocompromised individuals (3). The development of therapeutic antibodies against viruses has been impeded by high production costs and limited commercial market. Moreover, the relatively large size of antibodies, which results in correspondingly low tissue accessibility and penetration, affects their therapeutic efficacy (4). Therefore, smaller-sized antibodies and engineered variants have become promising alternatives to full-size mAbs (5).

In 1989, researchers reported the isolation of stable mouse antibody VH domains that could bind antigens with relatively high affinity $(20 \mathrm{nM})$, and the term "domain antibodies (dAbs)" was suggested (6). Moreover, in 1993, a unique class of "heavy-chain-only" antibodies (HCAbs) was found in the serum of camels. The variable domains of these HCAbs, referred to as VHHs, nanobodies (a term coined by Ablynx, a biopharmaceutical company) or single-domain antibodies (sdAbs) (7), represent the smallest naturally derived antigen-binding functional fragments $(\sim 15 \mathrm{kDa})$. These sdAbs maintain affinities and antigen-binding specificities comparable to those of full-size mAbs. Importantly, they are easy to engineer and more economical to produce; they also possess other unique and superior properties for a range of therapeutic applications. 
Here, we review sdAbs in relation to their possible therapeutic applications against highly aggressive human viral diseases. Potential sdAb-based therapeutics against viruses that are particularly important for public health, such as human immunodeficiency virus-1 (HIV-1), influenza A virus, respiratory syncytial virus (RSV), hepatitis C virus (HCV), and enteric viruses are discussed (Table $\mathbf{1}$ ). We also provide insight into the current status of the sdAbs, their ongoing development, as well as future challenges toward their successful implementation for therapy of human viral diseases.

TABLE 1 | Update of published sdAbs directed against viruses according to their binding sites [modified from Vanlandschoot et al. (8)].

\begin{tabular}{|c|c|c|c|c|c|c|c|}
\hline Binding sites & Reference & $\begin{array}{l}\text { Immunogen or } \\
\text { panning antigen }\end{array}$ & Origin & Mechanism & Potency in vitro & Breadth & $\ln v$ \\
\hline \multicolumn{8}{|c|}{ Extracellular targeting } \\
\hline $\begin{array}{l}\text { HIV CD4- } \\
\text { induced binding } \\
\text { site (coreceptor } \\
\text { binding site) }\end{array}$ & Chen et al. (9) & HIV-1 Envs & $\begin{array}{l}\text { Phage- } \\
\text { displayed } \\
\text { human VH } \\
\text { library }\end{array}$ & Neutralization & $\begin{array}{l}\text { Fusion proteins with } \\
\text { CD4 superior to bnAbs }\end{array}$ & Clade A, B, C, D & - \\
\hline $\begin{array}{l}\text { HIV coreceptor } \\
\text { binding site }\end{array}$ & Matz et al. (10) & Trimeric gp140 & Llama & Neutralization & $\mathrm{IC}_{50}: 0.2-40 \mu \mathrm{g} / \mathrm{ml}$ & $\begin{array}{l}\text { Subtypes A, C, } \\
\text { G, and CRF01_- } \\
\text { AE, CRF02_AG }\end{array}$ & - \\
\hline $\begin{array}{l}\text { HIV CD4- } \\
\text { binding site }\end{array}$ & McCoy et al. (11) & $\begin{array}{l}\text { Trimeric HIV-1 } \\
\text { gp140 }\end{array}$ & Llama & Neutralization & $\mathrm{IC}_{50}: 0.03-50 \mu \mathrm{g} / \mathrm{ml}$ & $\begin{array}{l}\text { Subtypes A, } \\
\text { B, C, D, G and } \\
\text { CRF_01 AE, } \\
\text { CRF_02AG, AC, } \\
\text { ACD, BC, and } \\
\text { CD }\end{array}$ & - \\
\hline
\end{tabular}

\begin{tabular}{|c|c|c|c|c|c|c|c|}
\hline HIV-1 MPER & Gong et al. (12) & $\begin{array}{l}\text { Gp41 MPER } \\
\text { peptide }\end{array}$ & $\mathrm{CH} 2$ library & Neutralization & - & Clade B, C, D, E & - \\
\hline HIV-1 MPER & Hulsik et al. (13) & Trimeric gp41 & Llama & Neutralization & $\begin{array}{l}\mathrm{IC}_{50} \text { bivalent: clade } \mathrm{A} \text { : } \\
2.4-4.6 \mu \mathrm{g} / \mathrm{ml} \text {; clade } \mathrm{B} \text { : } \\
0.2-33.4 \mu \mathrm{g} / \mathrm{ml}\end{array}$ & Clade A and B & - \\
\hline
\end{tabular}

\begin{tabular}{|c|c|c|c|c|c|c|c|}
\hline RSV F protein & Detalle et al. (14) & $\begin{array}{l}\text { Recombinant } \\
\text { F protein and } \\
\text { inactivated RSV-A }\end{array}$ & Llama & Neutralization & $\begin{array}{l}\mathrm{IC}_{50} \text { : subtype A: } \\
0.1 \mathrm{nM} \text {; subtype B: } \\
0.24 \mathrm{nM}\end{array}$ & $\begin{array}{l}\text { RSV A and B } \\
\text { subtypes }\end{array}$ & $\begin{array}{l}\text { Reducing both nasal } \\
\text { and lung RSV titers } \\
\text { prophylactically or } \\
\text { therapeutically }\end{array}$ \\
\hline $\begin{array}{l}\text { RSV prefusion F } \\
\text { protein }\end{array}$ & Rossey et al. (15) & $\begin{array}{l}\text { Prefusion } \\
\text { conformation, } \\
\text { DS-Cav1 }\end{array}$ & Llama & Neutralization & $\begin{array}{l}\mathrm{IC}_{50} \text { : subtype A: 0.038- } \\
0.089 \text { nM; subtype B: } \\
\text { 0.022-0.032 nM }\end{array}$ & $\begin{array}{l}\text { RSV A and B } \\
\text { subtypes }\end{array}$ & $\begin{array}{l}30 \mu \mathrm{g} \text { sdAbs } \\
\text { administered } \\
\text { intranasally prevent } \\
\text { RSV replication in } \\
\text { RSV-challenged mice }\end{array}$ \\
\hline Influenza M2 & Wei et al. (16) & M2 (H3N2) & $\begin{array}{l}\text { Synthetic } \\
\text { Camel VHH } \\
\text { library }\end{array}$ & Neutralization & $\begin{array}{l}\text { Minimal inhibitory } \\
\text { concentration at } \\
1.2 \mu \mathrm{M}\end{array}$ & $\mathrm{H} 3 \mathrm{~N} 2$ and $\mathrm{H} 1 \mathrm{~N} 1$ & $\begin{array}{l}200 \mu \mathrm{g} \text { antibodies } \\
\text { protect } 60 \% \text { mice with } \\
\text { H1N1 virus challenge }\end{array}$ \\
\hline Influenza HA & Ibanez et al. (17) & $\begin{array}{l}\text { Recombinant } \\
\text { H5N1-HA }\end{array}$ & Llama & Neutralization & - & $\mathrm{H} 5 \mathrm{~N} 1$ & $\begin{array}{l}\text { Prophylactic or } \\
\text { therapeutic treatment } \\
\text { to rescue mice against } \\
\text { H5N1 challenge }\end{array}$ \\
\hline Influenza HA & Tillib et al. (18) & $\begin{array}{l}\text { Inactivated H5N2 } \\
\text { virus }\end{array}$ & Camel & Neutralization & $\begin{array}{l}\text { Minimal inhibitory } \\
\text { concentration at } \\
4.2 \mathrm{nM}\end{array}$ & H5N2 & $\begin{array}{l}200 \mu \mathrm{g} \text { protect } 100 \% \\
\text { mice against virus } \\
\text { challenge }\end{array}$ \\
\hline Influenza HA & Hufton et al. (19) & $\begin{array}{l}\text { Recombinant } \\
\mathrm{H} 1-\mathrm{HA}\end{array}$ & Alpaca & Neutralization & $\mathrm{IC}_{50}: 3.2-212.2 \mathrm{nM}$ & $\mathrm{H} 1 \mathrm{~N} 1$ & - \\
\hline Influenza NA & Cardoso et al. (20) & N1rec & Alpaca & Neutralization & $\begin{array}{l}\mathrm{IC}_{50} \text { of monovalent: } \\
425.2 \text { and } 374.9 \mathrm{nM} \text {; } \\
\text { bivalent: } 0.157 \text { and } \\
0.69 \mathrm{nM}\end{array}$ & $\begin{array}{l}\text { Clade } 1 \text { and } 2 \\
\text { H5N1 }\end{array}$ & $\begin{array}{l}60 \mu \mathrm{g} \text { prophylactic } \\
\text { treatment protect } \\
100 \% \text { mice against a } \\
\text { lethal challenge with } \\
\mathrm{H} 5 \mathrm{~N} 1 \text { and oseltamivir- } \\
\text { resistant variant }\end{array}$ \\
\hline Influenza NA & Harmsen et al. (21) & $\begin{array}{l}\text { Mixtures of } \\
\text { purified influenza } \\
\text { viruses }\end{array}$ & Llama & - & - & All N subtypes & - \\
\hline
\end{tabular}


TABLE 1 | Continued

\begin{tabular}{|c|c|c|c|c|c|c|c|}
\hline Binding sites & Reference & $\begin{array}{l}\text { Immunogen or } \\
\text { panning antigen }\end{array}$ & Origin & Mechanism & Potency in vitro & Breadth & In vivo \\
\hline HCV E2 & Tarr et al. (22) & E2 glycoprotein & Alpaca & $\begin{array}{l}\text { Neutralization } \\
\text { and cell-to-cell } \\
\text { transmission }\end{array}$ & $\mathrm{IC}_{50}: 1-10 \mu \mathrm{g} / \mathrm{ml}$ & $\begin{array}{l}\text { Six major } \\
\text { genotypes }\end{array}$ & - \\
\hline $\begin{array}{l}\text { HSV-2 } \\
\text { glycoprotein D }\end{array}$ & $\begin{array}{l}\text { Geoghegan et al. } \\
(23)\end{array}$ & Recombinant gD2 & Llama & $\begin{array}{l}\text { Killing infected } \\
\text { cells by conjugated } \\
\text { immunotoxin }\end{array}$ & $\mathrm{IC}_{50}$ of $6.7 \mathrm{nM}$ & HSV-2 & - \\
\hline Rotavirus & $\begin{array}{l}\text { van der Vaart et al. } \\
(24)\end{array}$ & $\begin{array}{l}\text { Rhesus-monkey } \\
\text { rotavirus serotype } \\
\text { G3 }\end{array}$ & Llama & Neutralization & $\mid \mathrm{C}_{50}:<1 \mu \mathrm{g} / \mathrm{ml}$ & $\begin{array}{l}\text { G3 rotavirus } \\
\text { strain }\end{array}$ & $\begin{array}{l}\text { Reduce the morbidity } \\
\text { of rotavirus induced } \\
\text { diarrhea in mice }\end{array}$ \\
\hline Rotavirus VP6 & $\begin{array}{l}\text { Garaicoechea et al. } \\
\text { (25); Vega et al. } \\
\text { (26); Maffey et al. } \\
\text { (27) }\end{array}$ & VP6 protein & Llama & Neutralization & $\begin{array}{l}\mathrm{IC}_{80} \text { of monovalent: } \\
0.2-3.9 \mu \mathrm{g} / \mathrm{ml} \\
\text { bivalent: }>3.9 \mu \mathrm{g} / \mathrm{ml}\end{array}$ & $\begin{array}{l}\text { Group A } \\
\text { Rotavirus }\end{array}$ & $\begin{array}{l}\text { Monovalent VHH } \\
\text { protects and treats } \\
\text { against RVA-induced } \\
\text { diarrhea in mice and } \\
\text { gnotobiotic piglets }\end{array}$ \\
\hline $\begin{array}{l}\text { Norovirus P } \\
\text { domain of VLP }\end{array}$ & $\begin{array}{l}\text { Koromyslova and } \\
\text { Hansman (28) }\end{array}$ & Gll.10 VLP & Alpaca & $\begin{array}{l}\text { Particle } \\
\text { disassembly }\end{array}$ & - & $\begin{array}{l}\text { Gll.4, Gll.10, and } \\
\text { Gll.12 }\end{array}$ & - \\
\hline $\begin{array}{l}\text { Poliovirus } \\
\text { receptor-binding } \\
\text { site }\end{array}$ & $\begin{array}{l}\text { Thys et al. (29); } \\
\text { Schotte et al. (30); } \\
\text { Strauss et al. (31) }\end{array}$ & $\begin{array}{l}\text { Poliovirus type } 1 \\
\text { Sabin strain }\end{array}$ & Dromedary & Neutralization & $\begin{array}{l}I_{50}: 0.007-0.69 \mu \mathrm{M} \\
I C_{90}: 0.017-1.77 \mu \mathrm{M}\end{array}$ & Poliovirus type I & - \\
\hline \multicolumn{8}{|c|}{ Intracellular targeting } \\
\hline HIV Vpr & Matz et al. (32) & $\begin{array}{l}\text { Synthetic Vpr } \\
\text { peptide }\end{array}$ & Llama & $\begin{array}{l}\text { No inhibitory } \\
\text { activity }\end{array}$ & - & - & - \\
\hline $\begin{array}{l}\text { Influenza virus } \\
\text { nucleoprotein } \\
\text { (NP) }\end{array}$ & $\begin{array}{l}\text { Ashour et al. (33); } \\
\text { Hanke et al. (34) }\end{array}$ & $\begin{array}{l}\text { Influenza virus } \\
\text { PR8 }\end{array}$ & Alpaca & $\begin{array}{l}\text { Block vRNP } \\
\text { nuclear import, viral } \\
\text { transcription, and } \\
\text { replication }\end{array}$ & - & $\begin{array}{l}\text { Common } \\
\text { influenza virus } \\
\text { strains }\end{array}$ & - \\
\hline $\begin{array}{l}\text { Influenza virus } \\
\text { nucleoprotein } \\
\text { (NP) }\end{array}$ & Schmidt et al. (35) & Inactivated IAV & Alpaca & Block IAV infection & - & Influenza A virus & - \\
\hline HCV NS5B & $\begin{array}{l}\text { Thueng-in et al. } \\
\text { (36) }\end{array}$ & $\begin{array}{l}\text { NS5B } \Delta 55 \text { of } \\
\text { genotype } 3 a \mathrm{HCV}\end{array}$ & $\begin{array}{l}\text { Humanized- } \\
\text { camel phage } \\
\text { library }\end{array}$ & $\begin{array}{l}\text { Inhibition of RdRp } \\
\text { catalytic activity }\end{array}$ & $\begin{array}{l}2-4 \mu \mathrm{g} \text { inhibit RdRp } \\
\text { activity by } 10-69 \% \\
\text { and } 10 \mu \mathrm{g} \text { decrease } \\
\text { HCV RNA inside the } \\
\text { cells }\end{array}$ & HCV-JFH1 & - \\
\hline HCV NS3 & Phalaphol et al. (37) & rNS3-C & $\begin{array}{l}\text { Humanized- } \\
\text { camel phage } \\
\text { library }\end{array}$ & $\begin{array}{l}\text { Inhibition of } \\
\text { helicase activity }\end{array}$ & - & HCV-JFH1 & - \\
\hline $\begin{array}{l}\text { HCV serine } \\
\text { protease }\end{array}$ & $\begin{array}{l}\text { Jittavisutthikul et al. } \\
(38)\end{array}$ & $\mathrm{rNS} 3 / 4 \mathrm{~A}$ & $\begin{array}{l}\text { Humanized- } \\
\text { camel phage } \\
\text { library }\end{array}$ & $\begin{array}{l}\text { Inhibition of } \\
\text { protease activity }\end{array}$ & - & HCV-JFH1 & - \\
\hline $\begin{array}{l}\text { Ebola and } \\
\text { Marburg } \\
\text { nucleoprotein } \\
\text { (NP) }\end{array}$ & $\begin{array}{l}\text { Sherwood et al. } \\
(39,40) \text {; Darling } \\
\text { et al. (41) }\end{array}$ & $\begin{array}{l}\text { Ebolavirus or } \\
\text { MARV-Mus NP }\end{array}$ & $\begin{array}{l}\text { Single-pot } \\
\text { semisynthetic } \\
\text { Ilama library }\end{array}$ & $\begin{array}{l}\text { Inhibition of NP } \\
\text { packaging }\end{array}$ & - & Genus specific & - \\
\hline
\end{tabular}

-, Not determined.

\section{OVERVIEW OF ANTIVIRAL sdAbs}

Compared to the conventional human antibody $\mathrm{VH}$, a few crucial amino acids are substituted in the framework 2 region (FR2) and complementarity-determining regions (CDRs) of sdAbs. The highly conserved hydrophobic amino acids (Val47, Gly49, Leu50, Trp52) in FR2 region are replaced by hydrophilic amino acids (Phe42, Glu49, Arg50, Gly52) (Figure 1A) which are critical to the interaction of $\mathrm{V}_{\mathrm{H}}-\mathrm{V}_{\mathrm{L}}$, rendering the overall structure more hydrophilic and contributing to high stability, solubility and resistance to aggregation $(42,43)$. Moreover, sdAbs possess exceptional resistance to high temperatures and extreme $\mathrm{pH}(44)$, which makes them ideal candidates for developing viable treatment strategies against viruses in harsh environments such as the respiratory and gastrointestinal tracts. sdAbs can be easily administered via intranasal or oral route, directly to the site of viral infection $(25,45)$.

Owing to their increased hydrophilicity and single-polypeptide nature, sdAbs can be relatively efficiently produced in bacteria, 


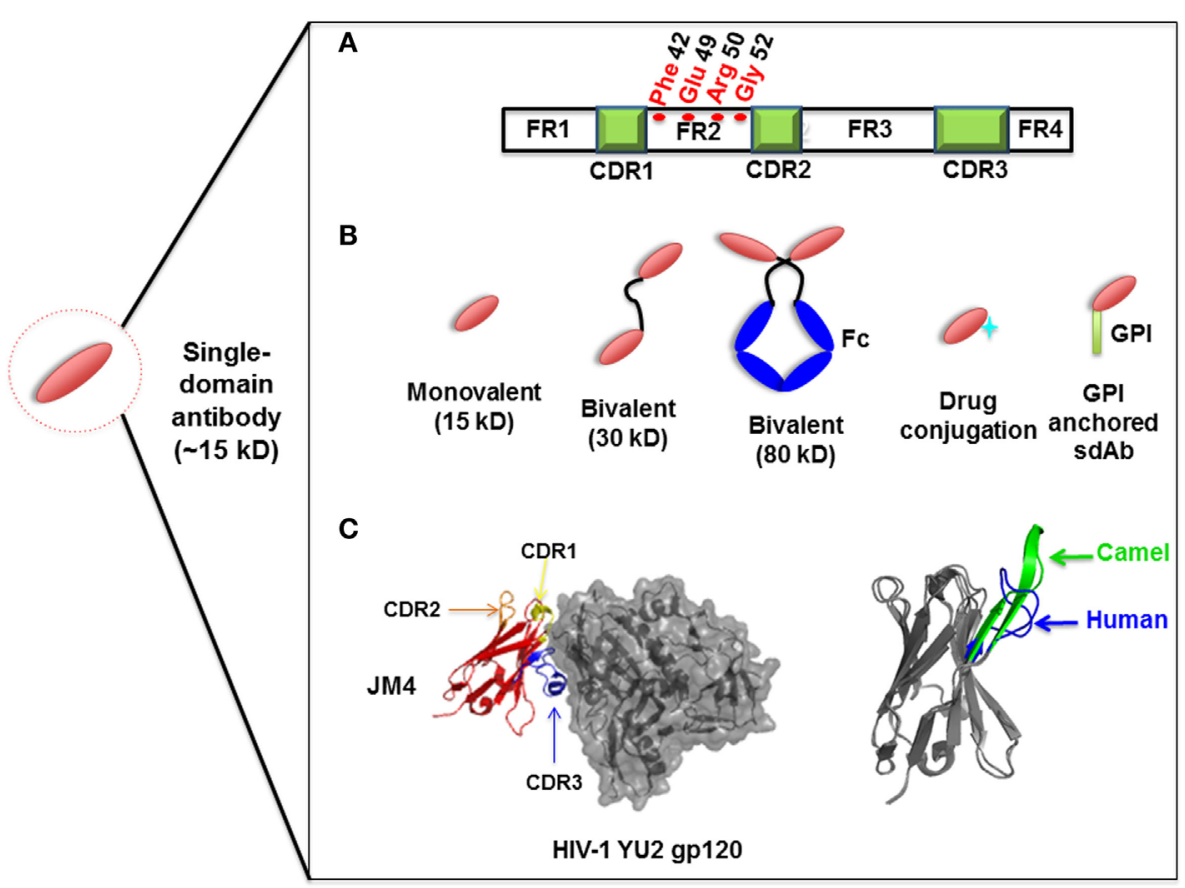

FIGURE 1 | Representation of single-domain antibodies (sdAbs) and their characteristics. (A) Representation of camelid sdAb framework (FR) and complementaritydetermining (CDR) regions, showing hydrophilic amino acids (Phe42, Glu49, Arg50, Gly52) in the FR2 region compared to conventional human VH (Val42, Gly49, Leu50, Trp52). (B) Schematic representation of sdAb-based engineered antibody constructs. (C) Neutralizing sdAb JM4 (PDB identifier 4LAJ) in complex with HIV-1 YU2 envelope gp120 glycoprotein, showing CDR1 (yellow), CDR2 (orange), and CDR3 (blue) and comparing CDR3 between human VH domain HEL4 (blue) (PDB identifier 1OHQ) and HIV-1 gp41 MPER-specific llama VHH 2H10 (green) (PDB identifier 4B50).

yeast, mammalian cells or plant cells, enabling large-scale production at reasonable costs. Plant cell expression systems, such as transgenic crops can provide a particularly low-cost option. sdAbs expressed in such crops as rice do not require purification and can be stored at room temperature for a long period without compromising antiviral activity (46), which is beneficial in some areas where cold chains are difficult to maintain.

The small size of sdAbs $(\sim 15 \mathrm{kDa})$ also allows rapid tissue penetration, including the blood-brain barrier (47) and even neurospheres, in comparison to full-size mAbs (48), thus holding promise for therapy of neurotropic virus infections like rabies virus. Rabies virus is a model neurotropic virus, which can cause lethal brain infection in humans. Postexposure treatment with antirabies sdAbs can partly rescue mice from lethal disease and decrease the viral RNA load in the brain. In contrast, treatments with vaccines or human antirabies immune globulins could not meet this test, indicating that antirabies sdAbs can enter the brain and neutralize virus $(49,50)$. Still, because of their short half-life, sdAbs may not have enough time to cross the endothelial barriers in sufficient amounts to clear out virus, thus limiting the effect of sdAb treatment at the more advanced stages of infection.

Structural analysis of sdAbs in complex with their antigens revealed that some sdAbs display an extended CDR3. The convex conformations formed by the CDR3 of these sdAbs (Figure 1C) can target unique and cryptic epitopes and confer unique binding specificities by blocking the concave epitopes of antigens $(31,51)$.
Single-domain antibodies can be easily engineered as multivalent constructs (Figure 1B). A number of studies indicated that multivalent formats are more effective than monovalent sdAbs in virus neutralization. For instance, it was found that a bivalent camelid $\mathrm{VHH}$ targeting $\mathrm{H} 5 \mathrm{~N} 1$ hemagglutinin was at least 60 -fold more effective than the monovalent one in controlling virus replication $(17,20)$. Moreover, conversion of influenza hemagglutinin-specific and cross-neutralizing antibodies into a bivalent format can increase their breadth of subtype crossreactive neutralization activity (19). ALX-0171, a trimeric RSV-neutralizing $\mathrm{VHH}$ that binds to an epitope similar to that of palivizumab, displayed more potent neutralization activity than palivizumab against prototypic RSV subtype A and B strains (14). Moreover, fusion with drugs, such as immunotoxins or cytotoxins, by site-specific conjugation to a C-terminal cysteine not only maintains the binding properties of sdAbs, but also increases their killing power against virus-infected cells (23) (Figure 2). Direct fusion to human serum albumin (HSA) (52) and PEGylation (53) can extend the serum half-life of sdAbs. However, such molecules have relatively large size that could lead to decreased inhibitory activity. Another attractive strategy for enhancing antibody pharmacokinetics by fusion to the Fc fragment of an IgG1 (54). Although these strategies increase the size of the antigen binders, the engineered molecules are still expected to target their epitopes more efficiently than full-length antibodies. A previous study reported improved half-life in vivo can be achieved by fusing sdAb with a small-sized HSA-binding 


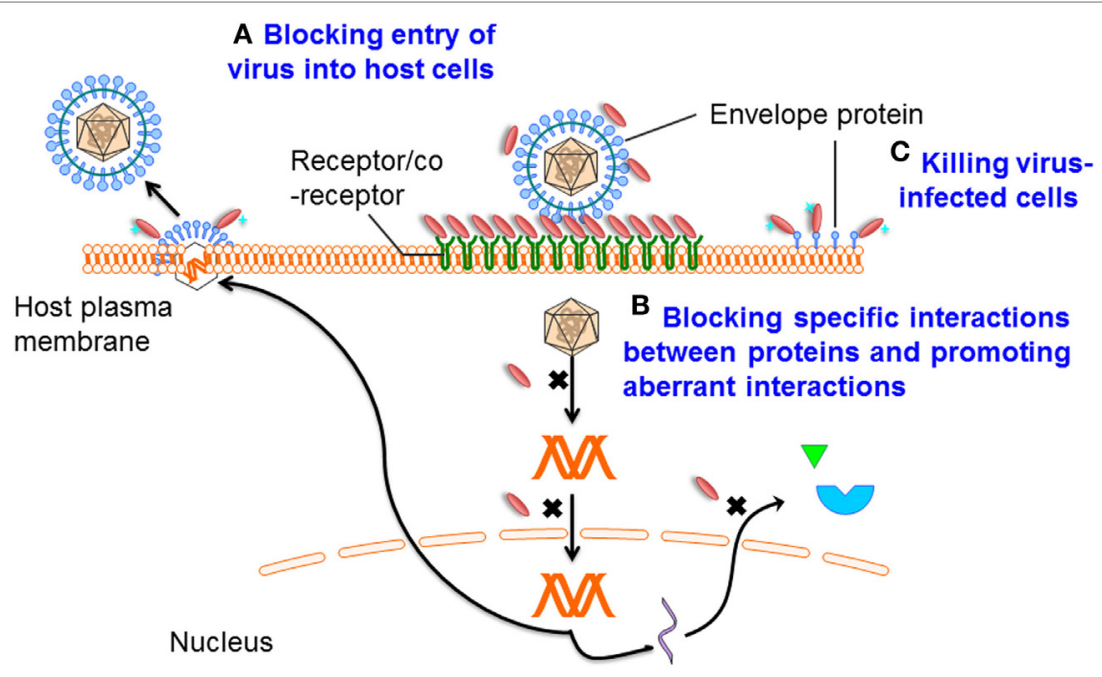

FIGURE 2 | Mechanisms of single-domain antibody (sdAb)-based therapeutics against viruses. Mechanism A: preventing entry of the viral particle into host cells by targeting viral envelope proteins or receptors that mediate cell binding and membrane fusion; mechanism B: blocking specific interactions between virus/virus or virus/host proteins, promoting aberrant interactions, binding in the active sites of enzymes, or through recognition or stabilization of distinct conformations of their targets; and mechanism C: specifically killing virus-infected cells by drug-conjugated or toxin-fused sdAbs.

peptide $(15-20 \mathrm{kDa})$ and the resultant fusion protein showed the same neutralizing activity as that of unconjugated $\mathrm{sdAb}(9)$.

Currently, small-molecule drugs are widely available to treat infections caused by HIV-1 (55), HBV (56), HCV (57), as well as influenza viruses (58). For instance, since the discovery of HIV-1, more than 30 compounds have been approved for the treatment of HIV-1 infection (59). These drugs demonstrate that a number of cytosolic proteins could serve as ideal targets for inhibition of viral infections. Although the penetration of sdAbs through the cell membrane remains a problematic issue, many sdAbs have sufficient inherent stability to be functional in antigen-binding, even in the absence of the disulfide bond as occurring in the reducing environment of the cytoplasm. When expressed as intrabodies, they can bind antigens to inhibit viral replication $(35,41)$. Furthermore, the high binding specificity of sdAbs can only rarely be achieved by small-molecule drugs. Analysis of V-D-J gene rearrangement shows that camelid sdAbs share high similarity (greater than $80 \%$ ) with the human IGHV3 gene family (44), indicating that the immunogenicity of camelid sdAbs could be low. Data from clinical trials of ALX-0171, an anti-RSV VHH, support this notion (45). These sdAbs can be "humanized" without significant loss of their specific activity (60). Moreover, a high-affinity and high-neutralization sdAb has been isolated from a large human $\mathrm{VH}$-based phage display library (9). Therefore, camelid sdAbs and fully human sdAbs have potential as therapeutics against viral infections.

\section{TARGETS OF ANTIVIRAL sdAbs}

\section{Proteins Mediating Entry of Viruses into Host Cells}

Infection is conditional on viral entry into host cells. Viral replication can then be initiated. This entry process is initially mediated by one or several viral proteins exposed on the virion surface and receptors or coreceptors on the host cell surface (61, 62). Proteins mediating viral entry are the promising targets for antibody-based antiviral therapy (Figure 2). Analysis of virus structure shows that many epitopes on the virion surface are hidden by deep invaginations or canyons and that they are, therefore, barely recognized by the large and typically flat antigen-binding sites of conventional antibodies $(15,63)$. More importantly, while many protruded epitopes on the viral surface are targeted by conventional antibodies, such epitopes can rapidly change conformation, resulting in the escape of virus from humoral immune responses (64). At the same time, these "hidden" epitopes, typically inaccessible to conventional antibodies, are well conserved across diverse viruses, making them good targets for sdAbs.

\section{sdAbs As Intrabodies Targeting Intracellular Proteins}

In the virus life cycle, many proteins encoded by viral genomes play essential roles in replication. Therefore, interfering with the virus life cycle by interrupting the functions of these proteins is another effective strategy (Figure 2), as already demonstrated by their successful targeting by small-molecule inhibitors. However, antibodies do not pass the plasma membranes. By gene transfer, intrabodies expressed in the cytoplasm may have broad antiviral therapeutic applications. As a consequence of the reducing environment of the cytoplasm, the formation of disulfide bonds is prevented. For most conventional mAbs, or their fragments, such as Fab and scFv, correct folding and stability generally depend on the formation of intra-domain disulfide bonds. Indeed, it has been shown that antibody fragments expressed in the reducing environment are strongly destabilized (65). In contrast, sdAbs can be functionally expressed in the cytoplasm (35), suggesting that their activities or stabilities are less dependent on the disulfide 
bond formation. Furthermore, Darling et al. advanced an alternative approach to generate a dimeric intracellularly expressed sdAb against Filoviruses which targeted highly conserved C-terminal regions of nucleoprotein (NP). This dimeric sdAb can restrict viral packaging and inhibit Marburg and Ebola replication (41). As such, sdAbs represent a rich source of functional intrabodies of potential therapeutic importance.

\section{sdAbs AS POTENTIAL THERAPEUTICS AGAINST VIRUSES}

\section{Human Immunodeficiency Virus 1}

The HIV-1 Env, a trimeric complex comprised of gp120 and gp41, typically serves as the main target for neutralizing antibodies. HIV-1 entry, the first step of the replication cycle, requires that gp120 engage the host cell surface CD4 and undergo a conformational change to bind either CCR5 or CXCR4, with subsequent fusion of cell and viral membrane mediated by gp41. Recently, a few highly potent and broadly neutralizing antibodies (bnAbs) have been identified from long-term HIV-infected individuals, including, for example, X5 (66), VRC01 (67), PGT121 (68), and $3 \mathrm{BNC} 117$ (69). Analysis of their binding models demonstrated that the key epitopes on gp120 for bnAbs are located at the CD4binding site (CD4bs) and the coreceptor-binding site (CoRbs). The CD4bs is formed as a hydrophobic and recessed pocket (70, 71). This pocket is surrounded by five loop structures, which partially overlay the site and may prevent access to large antibodies (72). CoRbs epitopes are usually inaccessible until gp120 changes its conformation upon CD4 binding. Therefore, these antibodies that specifically bind to exposed epitopes following CD4-gp120 binding are also termed as CD4-induced (CD4i) antibodies, which, however, are also masked by flanking V2 and V3 loops (70). Moreover, the close proximity of viral and cellular membranes leaves only a very narrow space which may not be sufficient to accommodate conventional Ig antibodies (73). The membrane proximal external region (MPER) epitopes on gp41 may also be size-restricted (63). In fact, the transient fusion-intermediate conformation of gp41 (74) is only accessible after the conformational changes induced by receptor/coreceptor binding in Env. It is obvious that these steric constraints require smaller antibody fragments which have smaller paratopes to access these regions. Because of their small size, protruding CDR3 loops, and cleft-recognition properties, sdAbs can reach such inaccessible epitopes and block entry, in many cases more efficiently than the corresponding Fab and scFv fragments and the full-size antibodies.

The first human sdAb, m36, identified from a human antibody variable domain phage-displayed library, targets a highly conserved sterically restricted region on gp120 induced by CD 4 binding. The neutralizing activity of $\mathrm{m} 36$ is, on average, higher than that of $\mathrm{scFv} \mathrm{m} 9$ that is a matured derivative of $\mathrm{X} 5$ and superior to other known first-generation HIV-1 bnAbs (9). Larger-sized IgG variants of this antibody exhibited a significant reduction in overall neutralization potency compared to m36 (9). To date, m36 is the only reported HIV-1 inhibitor with exceptional potency and broad cross-reactivity based on human dAbs.
Using trimeric gp140 as immunogen in llamas and gp120 for selection, a panel of broadly neutralizing camelid sdAbs (VHHs) were identified that can bind to either CD4bs or CoRbs (10). These camelid sdAbs exhibited potent neutralizing activity against viruses expressing subtype $B$ envelopes, including primary viral isolates resistant to some bnAbs, including 2G12, b12, 2F5, 4E10, PG9, and PG16 (10). One of the sdAbs, JM4, recognized a novel CD4i epitope including elements of both CD4bs and CoRbs (75). JM4 showed greater neutralization efficacy than known human CD4i IgGs as well as their Fab fragments, but IgG2b and IgG3 formats of JM4 showed dramatically enhanced breadth and potency (75). Further, Liu et al. developed GPI-anchored variable regions by genetically linking sdAbs with a glycosylphosphatidylinositol (GPI) attachment signal, which targeted lipid rafts of plasma membrane. Transduction of human $\mathrm{CD} 4^{+}$cell lines and primary CD4 T cells with GPI-VHH JM4 conferred broad and potent neutralization of HIV-1 and efficiently interfered with cell-cell transmission of HIV-1 and HIV-1 envelope-mediated fusion (76). One extremely potent and broad HIV-1-neutralizing sdAb from an immunized llama, J3, targeted the CD4-binding site and neutralized $96 \%$ of all strains tested (11). Notably, J3 exhibited high potency in blocking the cell-cell spread of HIV-1 from primary macrophages to CD4 T cells (77).

MPER-specific antibodies are among the broadest crossreactive HIV-1 neutralizing antibodies (78). However, numerous studies have been performed with purified gp41 proteins and gp41-derived peptides in an attempt to induce such antibodies by immunization, but such attempts have, thus far, met with little success $(79,80)$. An MPER-specific VHH, 2H10, whose epitope (EQELLELDK) partially overlaps with that of 2F5, was elicited by immunizing llamas with gp41-MPER proteoliposomes (81). $2 \mathrm{H} 10$ bound to a linear epitope of gp41 with low nanomolar affinity. Analysis of its crystal structure revealed an extended CDR3 with a solvent-exposed tryptophan (W100) at its tip, which is required for its neutralizing activity (13). Increasing affinity by increasing avidity, as demonstrated for bivalent $2 \mathrm{H} 10$, led to the neutralization of various sensitive and resistant strains, including some Tier 2 viruses, with 100-fold higher potency than mAb 2F5. Although bivalent $2 \mathrm{H} 10$ lacks the potency and breadth of 2F5, $4 \mathrm{E} 10$, or $10 \mathrm{E} 8$, optimization of the immunization protocol, such as longer immunization schemes, may produce more extensive somatic mutations and yield antibodies with higher breadth and potency. Interestingly, an IgG1 $\mathrm{CH} 2$ domain-based dAb was generated from a phage library. This dAb binds to MPER and can neutralize a limited number of HIV-1 isolates (12). It also binds to FcRn. The term nanoantibody was coined for such $\mathrm{CH} 2$-based dAbs because nanoantibodies can mimic some of the functions of full-size antibodies (82).

Previous studies have already found that anti-Nef and anti-Rev intracellular sdAbs could efficiently block most of the activities of these viral proteins $(83,84)$ to inhibit HIV-1 replication. The HIV-1 viral regulatory protein (Vpr) is involved in regulation of efficient virus replication, and known to induce cell cycle arrest, apoptosis, and the enhancement of HIV-1 transcription in infected cells. Matz et al. isolated a panel of anti-Vpr sdAbs from two libraries of VHHs elicited by two immunized llamas with either a synthetic Vpr peptide or recombinant HIV-1 capsid 
protein (32). One of these VHHs was able to bind Vpr in the cytoplasm of eukaryotic cells, leading to its delocalization from the nucleus to the cytoplasm, but had no effect on the activities of $\operatorname{Vpr}$ (32). This problem may be solved by fusing sdAb with an $\mathrm{SH} 3$ domain, demonstrated by one study from the same research group which found that Neffins, composed of an anti-Nef sdAb and modified SH3 domain, inhibited all key activities of HIV-1 Nef (85).

\section{Influenza A Virus}

Influenza viruses are currently classified into A, B, C, and D types on the basis of antigenic differences (86). In particular, highly pathogenic influenza A viruses occasionally cross the species barrier between domesticated birds and humans, such as the $\mathrm{H} 5$ and $\mathrm{H} 7$ subtypes, leading to seasonal epidemics and, sometimes, worldwide pandemics with high morbidity and mortality owing to severe and fatal acute respiratory diseases $(87,88)$. In the current decade, zoonotic outbreaks have posed significant threats to public health. However, currently available anti-influenza drugs are limited because of spontaneous virus mutations. Furthermore, such drugs often result in side effects and the emergence of drug-resistant viruses. Influenza A viruses are enveloped viruses antigenically consisting of two major membrane glycoproteins, hemagglutinin (HA), which mediates the binding of influenza virion to host cells and membrane fusion, and neuraminidase (NA), which is critical for the efficient release of newly synthesized influenza viruses by cleaving sialic acids from host cell receptor. While inhibitors specific for either the HA or NA glycoprotein $(89,90)$ can block virus infection, only HA glycoprotein mediates the virus entry process, making it a potential target for neutralizing antibodies. Several HA-targeting VHHs were isolated from llamas and were found to be specific for the H5N1 strain (17). One of these antibodies potently suppressed influenza A virus replication in vivo by intranasal administration. Bivalent antibodies showed 60-fold higher suppression than their monovalent counterparts and protected mice against a lethal challenge with H5N1 (17). In another study, Tillib et al. reported the development of potent camelid HA-specific sdAbs elicited by the immunization of a camel with inactivated avian influenza virus H5N2. The neutralizing activities of the original monovalent antiviral sdAbs are significantly enhanced both in vitro and in vivo by formatting procedure using the isoleucine zipper domain (ILZ) (18). The expression of ILZ formatted anti-HA sdAb in vivo for up to 14 days by an adenoviral vector resulted in prolonged protective effect against influenza virus (91). Decreased NA activities by blocking antibodies helped to protect a mouse model against H5N1 virus challenge (20).

Influenza M2 is a homotetrameric transmembrane protein that functions as a proton channel. M2 is required in several steps of influenza virus infection, including uncoating of the viral ribonucleoprotein core in endosomes, viral assembly and release $(92,93)$. In contrast to HA and NA, the N-terminal extracellular domain of M2 (M2e) has 24 residues remarkably conserved in all human influenza A strains. As such, neutralizing antibodies against $\mathrm{M} 2 \mathrm{e}$ are thought to offer broad protection. Indeed, M2-7A, an sdAb that specifically bound M2, showed broadly cross-reactive neutralization for both amantadine-sensitive and -resistant viruses in vitro and protected mice from lethal influenza virus challenge (16).

Given the continued relevance of influenza virus as a serious health threat and its ability to rapidly acquire resistance against drugs or escape from immune responses by antigenic drift, the less variable influenza virus proteins, including virus $\mathrm{NP}$, may prove to be alternative targets for intervention. A panel of sdAbs was generated against NP, a viral protein essential for nuclear trafficking and packaging of the influenza virus genome $(33,34)$. These sdAbs disrupt virus replication by preventing nuclear import of viral ribonucleoproteins (vRNPs). One such sdAb, termed as $\alpha$ NP$\mathrm{VHH} 1$, exhibited antiviral activity similar to that of Mx protein. Analysis of the crystal structure of this $\mathrm{VHH}$ in complex with NP revealed that the binding site overlaps regions associated with viral sensitivity to Mx proteins and is not conserved on the body domain of NP implicated in interactions with host factors (34). Schmidt et al. developed a highly efficient screening approach to identify antiviral sdAbs that confer a phenotype to cells when expressed intracellularly. Anti-NP sdAbs that specifically interact with their respective nucleoproteins protect human cells from lethal Influenza A virus infection by preventing nuclear import of viral vRNPs (35). So far, more than 20 NP-specific sdAbs have been characterized as binding to at least four unique binding sites on NP $(33,35)$. Continued efforts in this direction might help to map more precisely the contributions of different NP surfaces to the influenza virus life cycle and inspire the development of novel antivirals.

\section{Respiratory Syncytial Virus}

Respiratory syncytial virus infection causes serious or even fatal lower respiratory tract infections in infants. It is estimated that about 3.4 million infants are infected by RSV annually and more than 3 million of them develop severe bronchiolitis or pneumonia (94). Currently, neither licensed RSV vaccines nor specific anti-RSV therapeutics are available. RSV has two classes of transmembrane glycoproteins on the viral surface, fusion (F) protein, and attachment $(G)$ protein. Receptor binding is mediated by $\mathrm{G}$ protein, followed by fusion of viral and cell membrane and viral entry facilitated by F protein (95). Therefore, both proteins contain epitopes for neutralizing antibodies. The F protein shares high similarity between RSV subgroups A and B (89\% amino acid identity) and lower glycosylation compared to G protein, and is thus considered an ideal target for developing anti-RSV agents. The humanized mAb palivizumab (Synagis) binds to RSV F protein and neutralizes RSV by preventing fusion of the viral and host cell membrane (96). Although reducing hospitalizations when administered prophylactically, its high cost and limited efficacy have restricted its use to high-risk infants (97). Recently, an RSV-neutralizing, F protein-specific sdAb, Nb017, was identified from immune libraries of llamas (14). Fusion of three monovalent $\mathrm{Nb} 017 \mathrm{~s}$ linked by two GS linkers formed a trimeric antibody, ALX-0171, which binds antigenic site II epitope on RSV F, similar to that of palivizumab. ALX-0171 showed exceptional cross-reactive neutralization in vitro, much higher than that of palivizumab. Furthermore, ALX-0171, when directly delivered prophylactically or therapeutically to the sites of infection, was shown to be highly effective in reducing RSV replication in both 
nasal passage and lung (14). In a phase I/IIa trial, the viral loads in nasal swabs of hospitalized RSV-infected children were reduced by daily treatment for three consecutive days with ALX-0171 delivered by an inhalation device (45). Several studies reported that antibodies specifically binding to prefusion conformation of $\mathrm{F}$ protein exhibited more robust neutralizing activity than conformation-independent antibodies (98-100). Two llamaderived, prefusion F-specific sdAbs were identified to have neutralizing activity against RSV A and B subtypes superior to that of $\mathrm{mAb}$ palivizumab and motavizumab (15). Crystallization studies revealed that both sdAbs bind to a conserved cavity epitope formed by two F protomers, illustrating that the sdAbs preferentially bind to clefts or cavities. Prophylactic treatments with $30 \mu \mathrm{g}$ sdAbs administered intranasally prevented RSV replication in RSV-challenged mice (15). Such sdAbs with extraordinarily high RSV-neutralizing activity could be developed as therapeutics for the treatment of RSV infections.

\section{Hepatitis C Virus}

Hepatitis $C$ virus infection typically manifests as chronic hepatitis which often progresses to fatal cirrhosis and hepatocellular carcinoma. At present, no effective preventive treatment is available, and currently approved therapeutics are limited by relatively high cost (101). HCV envelope glycoprotein E2 is well conserved across all genotypes and can bind to host cell receptors, including $\mathrm{CD} 81$ and scavenger receptor class $\mathrm{B}$ type I (SR-BI), making E2 an attractive target for neutralizing antibodies (102). HCV E2-specific neutralizing antibodies have been shown to neutralize genetically diverse HCV isolates and effectively prevent and treat HCV infection in a human liver-chimeric mouse model (103) and chimpanzees (104). More recently, treatment of a neutralizing human mAb targeting HCV E2 significantly delayed viral rebound in patients infected with HCV 1a following liver transplantation (105). From a phage-library displaying an sdAb repertoire of alpaca immunized with HCV E2 glycoprotein, one E2-specific and potent cross-reactive neutralizing sdAb, D03, was identified. D03 recognizes a novel conserved epitope overlapping with that of the CD81 binding site. Structural analysis of D03 revealed a long CDR3 (20 residues) folding over part of the framework. Between the upstream part of CDR2 and CDR3, a disulfide bridge is formed that serves to restrict the flexibility of CDR3, thereby allowing maximal accessibility to the tip region of D03. D03 displayed potently neutralizing activity against a panel of HCV pseudoparticles representing six genotypes by interfering with E2-CD81 interaction, with an $\mathrm{IC}_{50}$ ranging between 1 and $10 \mu \mathrm{g} / \mathrm{ml}$ for most isolates. In addition, D03 efficiently inhibited cell-to-cell transmission of HCV, which is resistant to CD81 binding-site bnAbs (22). Although several sdAbs have entered clinical trials, this antibody is the first one that can prevent both cell-free and direct cell-to-cell transmission of a virus, highlighting its potential for the development as a clinically useful entry inhibitor.

A number of anti-NS5B, anti-NS3, and antiprotease sdAbs were identified from a humanized-camel naive $\mathrm{VHH}$ phagedisplay library (36-38). The three proteins are non-structural (NS) proteins, but with different enzymatic activities, and they are involved in $\mathrm{HCV}$ replication. By linking of these sdAbs to a cell-penetrating peptide, penetratin, these cell-penetrable sdAbs could suppress the heterologous HCV replication at different degrees, as shown by reduction of both intracellular and released viral RNA copies. Their recognized epitopes are located in the catalytic grooves of the enzymes. Therefore, a cocktail of sdAbs specific to multiple epitopes of HCV highly conserved regions and viral enzymes or enzymatically active proteins may be safe, broadly effective, and relatively mutation-tolerant anti-HCV agents.

\section{Herpes Simplex Virus 2}

Herpes simplex virus 2 is one of the most prevalent sexually transmitted viruses (106). HSV-2 infection is often described as a relatively mild and generally not life-threatening disease, but it is still one that significantly contributes to the acquisition of HIV-1 infection (107). Despite decades of intense research dedicated to preventing the sexual transmission of HSV-2, no broadly protective vaccine or therapeutic is available. Glycoprotein D (gD) mainly mediates membrane fusion by the interaction with its receptors, which serves as a key step for successful virus entry (108), as demonstrated by the finding that neutralizing antibodies targeting gD displayed effective protection against HSV infection (109). One gD-specific sdAb, R33, was identified from a VHH immune library obtained after immunizing a llama with HSV-2 $\mathrm{gD}$, but did not show neutralization against HSV-2 virus in vitro. Fusion of the cytotoxic domain of Pseudomonas aeruginosa exotoxin A (R33ExoA) to R33 did display specific and potent killing of HSV-2-infected cells, with an $\mathrm{IC}_{50}$ of $6.7 \mathrm{nM}$, indicating that R33 can deliver toxins or drugs to HSV-2-infected cells to reduce their nonspecific toxicity to normal cells and diminish side effects (23). This study confirmed that the antiviral activity of sdAbs could be increased by fusing them to toxins to generate immunotoxins.

\section{Enteric Viruses}

Up to now, gastroenteritis remains a critical health issue worldwide. Rotaviruses (RVs) and noroviruses (NoVs) are the two primary viral etiologies responsible for nonbacterial diarrhea in adults or children. Although the currently licensed rotavirus vaccines are efficacious in preventing rotavirus infection, no drugs have been approved for norovirus treatment. An antirotavirus $\mathrm{VHH}$ [termed antirotavirus protein (ARP1)] from a llama immunized with rhesus-monkey group A rotavirus (RVA) strain has been shown to neutralize 11 strains and displayed preventive and therapeutic potency against RVA-induced diarrhea in a neonatal mouse model $(24,46,110,111)$. Interestingly, mitigation of the symptoms was also achieved with freeze-dried ARP1, allowing it to be applied in areas where cold chains are difficult to maintain. Moreover, Pant et al. developed secreted or anchored antirotavirus $\mathrm{VHH}$ expressed in Lactobacillus paracasei to directly deliver therapeutic agents for the treatment of gastroenteritis $(110,111)$. Currently, the first clinical trial was performed in infants with RVA-associated diarrhea. This resulted in significant reduction in the frequency of stool output and no side effects after oral ARP1 therapy (112). Another $\mathrm{VHH}, 3 \mathrm{~B} 2$, which is specific to the inner capsid protein VP6, 
showed more broadly neutralizing capacity against RVA strains at lower doses (25). 3B2 conferred protection against RVAinduced diarrhea not only in neonatal mice (25), but also in gnotobiotic piglets (26), an animal model that has been widely used to study human RVA pathogenesis. Furthermore, postinfection therapeutic treatment with $3 \mathrm{~B} 2$ or $2 \mathrm{KD} 1$ in a neonatal mouse model significantly reduced duration of RVA-induced diarrhea (27).

Human NoVs are single-stranded RNA viruses whose capsid protein is composed of shell $(\mathrm{S})$ and protruding $(\mathrm{P})$ domains linked by a flexible hinge region (113). Because of the inability to cultivate NoVs in cells and continually evolving strains, no vaccines or therapeutics against $\mathrm{NoVs}$ are available. The lower region on the $\mathrm{P}$ domain contains several highly conserved residues among the genetically distinct genogroup II (GII) noroviruses, which is a dominant epitope recognized by broadly reactive mAbs (114, 115). Nano-85 and Nano-25 were isolated from alpha immunized with GII norovirus virus-like particles. They both bind to the region of $\mathrm{P}$ domain that forms occluded sites on the particles, as demonstrated by cryoelectron microscopy structures of sdAbs with viral particle complexes (28). Different from strain-dependent Nano-25, Nano-85 was broadly reactive to several different GII genotypes, including GII.4, GII.10, and GII.12. Furthermore, the binding of Nano-85 to intact particles caused the particles to disassemble in vitro (28), but the underlying mechanism needs to be further elucidated.

\section{CONCLUSION AND PERSPECTIVES}

In many cases, no vaccines or effective therapeutics are available to combat pathogenic viruses. As an alternative to full-size antibody-based antiviral therapeutics, sdAbs have begun to attract considerable scientific attention. sdAbs are characterized by their unique biophysical and pharmacological features, such as small size, high stability, excellent expression yield in prokaryotic and eukaryotic systems, and low immunogenicity. Antiviral sdAbs with nanomolar neutralization potency could be directly isolated from elicited sdAb repertoires of immunized animals when displayed on the surface of phage, yeast (116) or mammalian cells (35), or from large naive sdAb libraries (9). Moreover, sdAbs serve as excellent molecules for making multivalent constructs. Multimerization of sdAbs can easily increase affinity and potency. Fusion of several sdAbs that recognize different epitopes together might reduce the emergence of resistant virus during treatment. In this respect, sdAbs have an advantage over IgG, as the production of IgG-based bispecific antibodies involves the specific combination of four different polypeptides. Such novel multivalent constructs could be very effective in vivo. Finally, as

\section{REFERENCES}

1. Reichert JM. Antibodies to watch in 2017. mAbs (2017) 9(2):167-81. doi:10.10 80/19420862.2016.1269580

2. Weiner GJ. Building better monoclonal antibody-based therapeutics. Nat Rev Cancer (2015) 15(6):361-70. doi:10.1038/nrc3930

3. Scott LJ, Lamb HM. Palivizumab. Drugs (1999) 58(2):305-11; discussion 312-3. doi:10.2165/00003495-199958020-00009 discussed above, future research might focus on exploiting the ability of sdAbs, as intrabodies, to target intracellular proteins.

Despite these advantages, two major issues need to be addressed before sdAbs can be considered for in vivo use: their short half-life in circulation and possible immunogenicity. Their relatively short half-life in vivo could be improved by various strategies, most of which may, however, lead to increased size and decreased inhibitory activity. For instance, one of the most efficient strategies in extending half-life is to fuse sdAbs with human IgG1 Fc. IgG1 $\mathrm{Fc}$ can bind to the neonatal $\mathrm{Fc}_{\mathrm{C}}$ receptor $\left(\mathrm{FcRn}_{\mathrm{C}}\right)$ and rescue the fused sdAbs from endosomal degradation, but such fusion will result in greatly increasing the size of sdAbs from $\sim 15$ to $\sim 90 \mathrm{kDa}$. This could be partially addressed by the replacement of wild-type dimeric IgG1 Fc with some novel engineered Fc-based constructs. For example, we previously developed monomeric IgG1 $\mathrm{CH} 3$ or $\mathrm{CH} 2-\mathrm{CH} 3$ hybrids which have relatively small size $(\sim 15 \mathrm{kDa})$ and FcRn-binding capability (117-120). Such fusion proteins were easy to produce, stable, and retained the antigen-binding capability of the sdAbs $(117,121)$.

To reduce the risk of immunogenicity, strategies for the humanization of camelid-derived sdAbs have also become available in recent years. However, these strategies have some limitations, including the loss of heat refoldability upon humanization and the requirement to maintain two camelid residues within the FR2 (60). For biomedical applications, human VH sdAbs would be preferable because of the limited immunogenicity in patients. Although isolated human $\mathrm{VH}$ single domains generally display poor stability that causes aggregation, the poor biophysical properties of human $\mathrm{VH}$ single domains have recently been improved by the identification and introduction of mutations that allow maximal transfer of the hydrophobic to hydrophilic $\mathrm{V}_{\mathrm{H}} / \mathrm{V}_{\mathrm{L}}$ interface and do so by direct selection from phage libraries $(122,123)$. The grafting of CDRs from naive repertoire or immunized individuals into such human sdAb scaffolds could result in the development of fully human sdAbs against various targets. With advancing antibody-related technologies, we can anticipate the development of humanized or fully human sdAbs with minimal immunogenicity as commercially attractive therapeutics to fight viral diseases.

\section{AUTHOR CONTRIBUTIONS}

YW, SJ, and TY conceived and wrote the article.

\section{FUNDING}

This work was supported by the National Natural Science Foundation of China (31570936, 81630090, and 81561128006) and the 1000 Young Talents Program of China.

4. Samaranayake H, Wirth T, Schenkwein D, Räty JK, Ylä-Herttuala S. Challenges in monoclonal antibody-based therapies. Ann Med (2009) 41(5):322-31. doi:10.1080/07853890802698842

5. Holliger P, Hudson PJ. Engineered antibody fragments and the rise of single domains. Nat Biotech (2005) 23(9):1126-36. doi:10.1038/nbt1142

6. Ward ES, Gussow D, Griffiths AD, Jones PT, Winter G. Binding activities of a repertoire of single immunoglobulin variable domains secreted from Escherichia coli. Nature (1989) 341(6242):544-6. doi:10.1038/341544a0 
7. Hamers-Casterman C, Atarhouch T, Muyldermans S. Naturally occurring antibodies devoid of light chains. Nature (1993) 363(6428):446-8. doi:10.1038/363446a0

8. Vanlandschoot P, Stortelers C, Beirnaert E, Ibañez LI, Schepens B, Depla E, et al. Nanobodies ${ }^{\circledast}$ : new ammunition to battle viruses. Antiviral Res (2011) 92(3):389-407. doi:10.1016/j.antiviral.2011.09.002

9. Chen W, Zhu Z, Feng Y, Dimitrov DS. Human domain antibodies to conserved sterically restricted regions on gp120 as exceptionally potent cross-reactive HIV-1 neutralizers. Proc Natl Acad Sci U S A (2008) 105(44):17121-6. doi:10.1073/pnas.0805297105

10. Matz J, Kessler P, Bouchet J, Combes O, Ramos OH, Barin F, et al. Straightforward selection of broadly neutralizing single-domain antibodies targeting the conserved CD4 and coreceptor binding sites of HIV-1 gp120. J Virol (2013) 87(2):1137-49. doi:10.1128/JVI.00461-12

11. McCoy LE, Quigley AF, Strokappe NM, Bulmer-Thomas B, Seaman MS, Mortier D, et al. Potent and broad neutralization of HIV-1 by a llama antibody elicited by immunization. J Exp Med (2012) 209(6):1091-103. doi:10.1084/ jem.20112655

12. Gong R, Wang Y, Ying T, Dimitrov DS. Bispecific engineered antibody domains (nanoantibodies) that interact noncompetitively with an HIV-1 neutralizing epitope and FcRn. PLoS One (2012) 7(8):e42288. doi:10.1371/ journal.pone. 0042288

13. Lutje Hulsik D, Liu YY, Strokappe NM, Battella S, El Khattabi M, McCoy LE, et al. A gp41 MPER-specific llama VHH requires a hydrophobic CDR3 for neutralization but not for antigen recognition. PLoS Pathog (2013) 9(3):e1003202. doi:10.1371/journal.ppat.1003202

14. Detalle L, Stohr T, Palomo C, Piedra PA, Gilbert BE, Mas V, et al. Generation and characterization of ALX-0171, a potent novel therapeutic nanobody for the treatment of respiratory syncytial virus infection. Antimicrob Agents Chemother (2015) 60(1):6-13. doi:10.1128/AAC.01802-15

15. Rossey I, Gilman MS, Kabeche SC, Sedeyn K, Wrapp D, Kanekiyo M, et al. Potent single-domain antibodies that arrest respiratory syncytial virus fusion protein in its prefusion state. Nat Commun (2017) 8:14158. doi:10.1038/ ncomms 14158

16. Wei G, Meng W, Guo H, Pan W, Liu J, Peng T, et al. Potent neutralization of influenza A virus by a single-domain antibody blocking M2 ion channel protein. PLoS One (2011) 6(12):e28309. doi:10.1371/journal.pone.0028309

17. Ibanez LI, De Filette M, Hultberg A, Verrips T, Temperton N, Weiss RA, et al. Nanobodies with in vitro neutralizing activity protect mice against H5N1 influenza virus infection. J Infect Dis (2011) 203(8):1063-72. doi:10.1093/infdis/jiq168

18. Tillib SV, Ivanova TI, Vasilev LA, Rutovskaya MV, Saakyan SA, Gribova IY, et al. Formatted single-domain antibodies can protect mice against infection with influenza virus (H5N2). Antiviral Res (2013) 97(3):245-54. doi:10.1016/j. antiviral.2012.12.014

19. Hufton SE, Risley P, Ball CR, Major D, Engelhardt OG, Poole S. The breadth of cross sub-type neutralisation activity of a single domain antibody to influenza hemagglutinin can be increased by antibody valency. PLoS One (2014) 9(8):e103294. doi:10.1371/journal.pone.0103294

20. Cardoso FM, Ibanez LI, Van den Hoecke S, De Baets S, Smet A, Roose K, et al. Single-domain antibodies targeting neuraminidase protect against an H5N1 influenza virus challenge. J Virol (2014) 88(15):8278-96. doi:10.1128/ JVI.03178-13

21. Harmsen M, Blokker J, Pritz-Verschuren S, BartelinkW, van der Burg H, Koch G. Isolation of panels of llama single-domain antibody fragments binding all nine neuraminidase subtypes of influenza A virus. Antibodies (2013) 2(2):168-92. doi:10.3390/antib2020168

22. Tarr AW, Lafaye P, Meredith L, Damier-Piolle L, Urbanowicz RA, Meola A, et al. An alpaca nanobody inhibits hepatitis $C$ virus entry and cell-to-cell transmission. Hepatology (2013) 58(3):932-9. doi:10.1002/hep.26430

23. Geoghegan EM, Zhang H, Desai PJ, Biragyn A, Markham RB. Antiviral activity of a single-domain antibody immunotoxin binding to glycoprotein $\mathrm{D}$ of herpes simplex virus 2. Antimicrob Agents Chemother (2015) 59(1):527-35. doi:10.1128/AAC.03818-14

24. van der Vaart JM, Pant N, Wolvers D, Bezemer S, Hermans PW, Bellamy K, et al. Reduction in morbidity of rotavirus induced diarrhoea in mice by yeast produced monovalent llama-derived antibody fragments. Vaccine (2006) 24(19):4130-7. doi:10.1016/j.vaccine.2006.02.045

25. Garaicoechea L, Olichon A, Marcoppido G, Wigdorovitz A, Mozgovoj M, SaifL, et al. Llama-derived single-chain antibody fragments directed to rotavirus
VP6 protein possess broad neutralizing activity in vitro and confer protection against diarrhea in mice. J Virol (2008) 82(19):9753-64. doi:10.1128/ JVI.00436-08

26. Vega CG, Bok M, Vlasova AN, Chattha KS, Gomez-Sebastian S, Nunez C, et al. Recombinant monovalent llama-derived antibody fragments (VHH) to rotavirus VP6 protect neonatal gnotobiotic piglets against human rotavirus-induced diarrhea. PLoS Pathog (2013) 9(5):e1003334. doi:10.1371/ journal.ppat.1003334

27. Maffey L, Vega CG, Miño S, Garaicoechea L, Parreño V. Anti-VP6 VHH: an experimental treatment for rotavirus A-associated disease. PLoS One (2016) 11(9):e0162351. doi:10.1371/journal.pone.0162351

28. Koromyslova AD, Hansman GS. Nanobody binding to a conserved epitope promotes norovirus particle disassembly. J Virol (2015) 89(5):2718-30. doi:10.1128/JVI.03176-14

29. Thys B, Schotte L, Muyldermans S, Wernery U, Hassanzadeh-Ghassabeh G, Rombaut B. In vitro antiviral activity of single domain antibody fragments against poliovirus. Antiviral Res (2010) 87(2):257-64. doi:10.1016/j. antiviral.2010.05.012

30. Schotte L, Strauss M, Thys B, Halewyck H, Filman DJ, Bostina M, et al. Mechanism of action and capsid-stabilizing properties of VHHs with an in vitro antipolioviral activity. J Virol (2014) 88(8):4403-13. doi:10.1128/ JVI.03402-13

31. Strauss M, Schotte L, Thys B, Filman DJ, Hogle JM. Five of five VHHs neutralizing poliovirus bind the receptor-binding site. J Virol (2016) 90(7):3496-505. doi:10.1128/JVI.03017-15

32. Matz J, Herate C, Bouchet J, Dusetti N, Gayet O, Baty D, et al. Selection of intracellular single-domain antibodies targeting the HIV-1 Vpr protein by cytoplasmic yeast two-hybrid system. PLoS One (2014) 9(12):e113729. doi:10.1371/journal.pone.0113729

33. Ashour J, Schmidt FI, Hanke L, Cragnolini J, Cavallari M, Altenburg A, et al. Intracellular expression of camelid single-domain antibodies specific for influenza virus nucleoprotein uncovers distinct features of its nuclear localization. J Virol (2015) 89(5):2792-800. doi:10.1128/JVI.02693-14

34. Hanke L, Knockenhauer KE, Brewer RC, van Diest E, Schmidt FI, Schwartz TU, et al. The antiviral mechanism of an influenza A virus nucleoprotein-specific single-domain antibody fragment. MBio (2016) 7(6):e01569-16. doi:10.1128/ mBio.01569-16

35. Schmidt FI, Hanke L, Morin B, Brewer R, Brusic V, Whelan SP, et al. Phenotypic lentivirus screens to identify functional single domain antibodies. Nat Microbiol (2016) 1(8):16080. doi:10.1038/nmicrobiol.2016.80

36. Thueng-in K, Thanongsaksrikul J, Srimanote P, Bangphoomi K, Poungpair O, Maneewatch S, et al. Cell penetrable humanized- $\mathrm{VH} / \mathrm{V}(\mathrm{H}) \mathrm{H}$ that inhibit RNA dependent RNA polymerase (NS5B) of HCV. PLoS One (2012) 7(11):e49254. doi:10.1371/journal.pone.0049254

37. Phalaphol A, Thueng-In K, Thanongsaksrikul J, Poungpair O, Bangphoomi K, Sookrung N, et al. Humanized-VH/VHH that inhibit HCV replication by interfering with the virus helicase activity. J Virol Methods (2013) 194(1-2): 289-99. doi:10.1016/j.jviromet.2013.08.032

38. JittavisutthikulS, ThanongsaksrikulJ, Thueng-In K, Chulanetra M, Srimanote $\mathrm{P}$, Seesuay W, et al. Humanized-VHH transbodies that inhibit HCV protease and replication. Viruses (2015) 7(4):2030-56. doi:10.3390/v7042030

39. Sherwood LJ, Osborn LE, Carrion R, Patterson JL, Hayhurst A. Rapid assembly of sensitive antigen-capture assays for Marburg virus, using in vitro selection of llama single-domain antibodies, at biosafety level 4. J Infect Dis (2007) 196:S213-9. doi:10.1086/520586

40. Sherwood LJ, Hayhurst A. Ebolavirus nucleoprotein C-termini potently attract single domain antibodies enabling monoclonal affinity reagent sandwich assay (MARSA) formulation. PLoS One (2013) 8(4):e61232. doi:10.1371/ journal.pone.0061232

41. Darling TL, Sherwood LJ, Hayhurst A. Intracellular crosslinking of filoviral nucleoproteins with xintrabodies restricts viral packaging. Front Immunol (2017) 8:1197. doi:10.3389/fimmu.2017.01197

42. Muyldermans S, Atarhouch T, Saldanha J, Barbosa JARG, Hamers R. Sequence and structure of $\mathrm{V}-\mathrm{H}$ domain from naturally-occurring camel heavy-chain immunoglobulins lacking light-chains. Protein Eng (1994) 7(9):1129-35. doi:10.1093/Protein/7.9.1129

43. Vu KB, Ghahroudi MA, Wyns L, Muyldermans S. Comparison of llama V-H sequences from conventional and heavy chain antibodies. Mol Immunol (1997) 34(16-17):1121-31. doi:10.1016/S0161-5890(97)00146-6 
44. Muyldermans S. Nanobodies: natural single-domain antibodies. Annu Rev Biochem (2013) 82:775-97. doi:10.1146/annurev-biochem-063011092449

45. Van Heeke G, Allosery K, De Brabandere V, De Smedt T, Detalle L, de Fougerolles A. Nanobodies ${ }^{\circledast}$ as inhaled biotherapeutics for lung diseases. Pharmacol Ther (2017) 169:47-56. doi:10.1016/j.pharmthera.2016.06.012

46. Tokuhara D, Alvarez B, Mejima M, Hiroiwa T, Takahashi Y, Kurokawa S, et al. Rice-based oral antibody fragment prophylaxis and therapy against rotavirus infection. J Clin Invest (2013) 123(9):3829-38. doi:10.1172/JCI70266

47. Rutgers KS, Nabuurs RJA, van den Berg SAA, Schenk GJ, Rotman M, Verrips CT, et al. Transmigration of beta amyloid specific heavy chain antibody fragments across the in vitro blood-brain barrier. Neuroscience (2011) 190:37-42. doi:10.1016/j.neuroscience.2011.05.076

48. Rotman M, Welling MM, Bunschoten A, de Backer ME, Rip J, Nabuurs RJA, et al. Enhanced glutathione PEGylated liposomal brain delivery of an anti-amyloid single domain antibody fragment in a mouse model for Alzheimer's disease. J Control Release (2015) 203:40-50. doi:10.1016/j. jconrel.2015.02.012

49. Terryn S, Francart A, Lamoral S, Hultberg A, Rommelaere H, Wittelsberger A, et al. Protective effect of different anti-rabies virus VHH constructs against rabies disease in mice. PLoS One (2014) 9(10):e109367. doi:10.1371/journal. pone.0109367

50. Terryn S, Francart A, Rommelaere H, Stortelers C, Van Gucht S. Postexposure treatment with anti-rabies $\mathrm{VHH}$ and vaccine significantly improves protection of mice from lethal rabies infection. PLoS Negl Trop Dis (2016) 10(8):e0004902. doi:10.1371/journal.pntd.0004902

51. Garza JA, Taylor AB, Sherwood LJ, Hart PJ, Hayhurst A. Unveiling a drift resistant cryptotope within marburgvirus nucleoprotein recognized by llama single-domain antibodies. Front Immunol (2017) 8:1234. doi:10.3389/ fimmu.2017.01234

52. Muller D, Karle A, Meissburger B, Hofig I, Stork R, Kontermann RE. Improved pharmacokinetics of recombinant bispecific antibody molecules by fusion to human serum albumin. J Biol Chem (2007) 282(17):12650-60. doi:10.1074/ jbc.M700820200

53. Veronese FM, Mero A. The impact of PEGylation on biological therapies. BioDrugs (2008) 22(5):315-29. doi:10.2165/00063030-200822050-00004

54. Bell A, Wang ZJ, Arbabi-Ghahroudi M, Chang TA, Durocher Y, Trojahn U, et al. Differential tumor-targeting abilities of three single-domain antibody formats. Cancer Lett (2010) 289(1):81-90. doi:10.1016/j.canlet.2009.08.003

55. Heredia A, Latinovic OS, Barbault F, de Leeuw EP. A novel small-molecule inhibitor of HIV-1 entry. Drug Des Devel Ther (2015) 9:5469-78. doi:10.2147/ DDDT.S89338

56. Qiu LP, Chen L, Chen KP. Antihepatitis B therapy: a review of current medications and novel small molecule inhibitors. Fundam Clin Pharmacol (2014) 28(4):364-81. doi:10.1111/fcp.12053

57. Meanwell NA, Philip S. Portoghese medicinal chemistry lectureship. curing hepatitis $\mathrm{C}$ virus infection with direct-acting antiviral agents: the arc of a medicinal chemistry triumph. J Med Chem (2016) 59(16):7311-51. doi:10.1021/acs.jmedchem.6b00915

58. Lee KK, Pessi A, Gui L, Santoprete A, Talekar A, Moscona A, et al. Capturing a fusion intermediate of influenza hemagglutinin with a cholesterol-conjugated peptide, a new antiviral strategy for influenza virus. J Biol Chem (2011) 286(49):42141-9. doi:10.1074/jbc.M111.254243

59. Flexner C, Saag M. The antiretroviral drug pipeline: prospects and implications for future treatment research. Curr Opin HIV AIDS (2013) 8(6):572-8. doi:10.1097/COH.0000000000000011

60. Vincke C, Loris R, Saerens D, Martinez-Rodriguez S, Muyldermans S, Conrath K. General strategy to humanize a camelid single-domain antibody and identification of a universal humanized nanobody scaffold. J Biol Chem (2009) 284(5):3273-84. doi:10.1074/jbc.M806889200

61. Plemper RK. Cell entry of enveloped viruses. Curr Opin Virol (2011) 1(2):92-100. doi:10.1016/j.coviro.2011.06.002

62. Tan M, Hegde RS, Jiang X. The P domain of norovirus capsid protein forms dimer and binds to histo-blood group antigen receptors. J Virol (2004) 78(12):6233-42. doi:10.1128/JVI.78.12.6233-6242.2004

63. Klein JS, Gnanapragasam PN, Galimidi RP, Foglesong CP, West AP Jr, Bjorkman PJ. Examination of the contributions of size and avidity to the neutralization mechanisms of the anti-HIV antibodies b12 and 4E10. Proc Natl Acad Sci U S A (2009) 106(18):7385-90. doi:10.1073/pnas.0811427106
64. Ouyang Y, Yin Q, Li W, Li Z, Kong D, Wu Y, et al. Escape from humoral immunity is associated with treatment failure in HIV-1-infected patients receiving long-term antiretroviral therapy. Sci Rep (2017) 7(1):6222. doi:10.1038/ s41598-017-05594-5

65. Worn A, der Maur AA, Escher D, Honegger A, Barberis A, Pluckthun A. Correlation between in vitro stability and in vivo performance of anti-GCN4 intrabodies as cytoplasmic inhibitors. J Biol Chem (2000) 275(4):2795-803. doi:10.1074/Jbc.275.4.2795

66. Xiang SH, Doka N, Choudhary RK, Sodroski J, Robinson JE. Characterization of CD4-induced epitopes on the HIV type 1 gp120 envelope glycoprotein recognized by neutralizing human monoclonal antibodies. AIDS Res Hum Retroviruses (2002) 18(16):1207-17. doi:10.1089/08892220260387959

67. Wu X, Yang ZY, Li Y, Hogerkorp CM, Schief WR, Seaman MS, et al. Rational design of envelope identifies broadly neutralizing human monoclonal antibodies to HIV-1. Science (2010) 329(5993):856-61. doi:10.1126/science.1187659

68. Walker LM, Huber M, Doores KJ, Falkowska E, Pejchal R, Julien JP, et al. Broad neutralization coverage of HIV by multiple highly potent antibodies. Nature (2011) 477(7365):466-70. doi:10.1038/nature10373

69. Scheid JF, Mouquet H, Ueberheide B, Diskin R, Klein F, Oliveira TY, et al. Sequence and structural convergence of broad and potent HIV antibodies that mimic CD4 binding. Science (2011) 333(6049):1633-7. doi:10.1126/ science. 1207227

70. Wyatt R, Kwong PD, Desjardins E, Sweet RW, Robinson J, Hendrickson WA, et al. The antigenic structure of the HIV gp120 envelope glycoprotein. Nature (1998) 393(6686):705-11. doi:10.1038/31514

71. Kwong PD, Wyatt R, Robinson J, Sweet RW, Sodroski J, Hendrickson WA. Structure of an HIV gp120 envelope glycoprotein in complex with the CD4 receptor and a neutralizing human antibody. Nature (1998) 393(6686):648-59. doi:10.1038/31405

72. Berkower I, Patel C, Ni Y, Virnik K, Xiang Z, Spadaccini A. Targeted deletion in the beta20-beta21 loop of HIV envelope glycoprotein gp120 exposes the CD4 binding site for antibody binding. Virology (2008) 377(2):330-8. doi:10.1016/j.virol.2008.03.040

73. Labrijn AF, Poignard P, Raja A, Zwick MB, Delgado K, Franti M, et al. Access of antibody molecules to the conserved coreceptor binding site on glycoprotein gp120 is sterically restricted on primary human immunodeficiency virus type 1. J Virol (2003) 77(19):10557-65. doi:10.1128/JVI.77.19.10557-10565.2003

74. Frey G, Peng H, Rits-Volloch S, Morelli M, Cheng Y, Chen B. A fusion-intermediate state of HIV-1 gp41 targeted by broadly neutralizing antibodies. Proc Natl Acad Sci U S A (2008) 105(10):3739-44. doi:10.1073/pnas.0800255105

75. Acharya P, Luongo TS, Georgiev IS, Matz J, Schmidt SD, Louder MK, et al. Heavy chain-only IgG2b llama antibody effects near-pan HIV-1 neutralization by recognizing a CD4-induced epitope that includes elements of coreceptor- and CD4-binding sites. J Virol (2013) 87(18):10173-81. doi:10.1128/ JVI.01332-13

76. Liu L, Wang W, Matz J, Ye C, Bracq L, Delon J, et al. The glycosylphosphatidylinositol-anchored variable region of llama heavy chain-only antibody JM4 efficiently blocks both cell-free and T cell- $\mathrm{T}$ cell transmission of human immunodeficiency virus type 1. J Virol (2016) 90(23):10642-59. doi:10.1128/ JVI.01559-16

77. McCoy LE, Groppelli E, Blanchetot C, de Haard H, Verrips T, Rutten L, et al. Neutralisation of HIV-1 cell-cell spread by human and llama antibodies. Retrovirology (2014) 11:83. doi:10.1186/s12977-014-0083-y

78. Huang J, Ofek G, Laub L, Louder MK, Doria-Rose NA, Longo NS, et al. Broad and potent neutralization of HIV-1 by a gp41-specific human antibody. Nature (2012) 491(7424):406-12. doi:10.1038/nature11544

79. Qiao ZS, Kim M, Reinhold B, Montefiori D, Wang JH, Reinherz EL. Design, expression, and immunogenicity of a soluble HIV trimeric envelope fragment adopting a prefusion gp41 configuration. J Biol Chem (2005) 280(24):2313846. doi:10.1074/jbc.M414515200

80. Zhou M, Kostoula I, Brill B, Panou E, Sakarellos-Daitsiotis M, Dietrich U. Prime boost vaccination approaches with different conjugates of a new HIV-1 gp41 epitope encompassing the membrane proximal external region induce neutralizing antibodies in mice. Vaccine (2012) 30(11):1911-6. doi:10.1016/j. vaccine.2012.01.026

81. Ofek G, Tang M, Sambor A, Katinger H, Mascola JR, Wyatt R, et al. Structure and mechanistic analysis of the anti-human immunodeficiency virus type 1 antibody 2F5 in complex with its gp41 epitope. J Virol (2004) 78(19):10724-37. doi:10.1128/JVI.78.19.10724-10737.2004 
82. Dimitrov DS. Engineered CH2 domains (nanoantibodies). MAbs (2009) 1(1):26-8. doi:10.4161/mabs.1.1.7480

83. Bouchet J, Basmaciogullari SE, Chrobak P, Stolp B, Bouchard N, Fackler OT, et al. Inhibition of the Nef regulatory protein of HIV-1 by a single-domain antibody. Blood (2011) 117(13):3559-68. doi:10.1182/ blood-2010-07-296749

84. Vercruysse T, Pardon E, Vanstreels E, Steyaert J, Daelemans D. An intrabody based on a llama single-domain antibody targeting the $\mathrm{N}$-terminal alpha-helical multimerization domain of HIV-1 rev prevents viral production. J Biol Chem (2010) 285(28):21768-80. doi:10.1074/jbc.M110.112490

85. Bouchet J, Herate C, Guenzel CA, Verollet C, Jarviluoma A, Mazzolini J, et al. Single-domain antibody-SH3 fusions for efficient neutralization of HIV-1 Nef functions. J Virol (2012) 86(9):4856-67. doi:10.1128/JVI.06329-11

86. Hause BM, Collin EA, Liu R, Huang B, Sheng Z, Lu W, et al. Characterization of a novel influenza virus in cattle and Swine: proposal for a new genus in the Orthomyxoviridae family. MBio (2014) 5(2):e31-14. doi:10.1128/ mBio.00031-14

87. Gao R, Cao B, Hu Y, Feng Z, Wang D, Hu W, et al. Human infection with a novel avian-origin influenza A (H7N9) virus. $N$ Engl J Med (2013) 368(20):1888-97. doi:10.1056/NEJMoa1304459

88. Tscherne DM, García-Sastre A. Virulence determinants of pandemic influenza viruses. J Clin Invest (2011) 121(1):6-13. doi:10.1172/jci44947

89. Basu A, Antanasijevic A, Wang M, Li B, Mills DM, Ames JA, et al. New small molecule entry inhibitors targeting hemagglutinin-mediated influenza a virus fusion. J Virol (2014) 88(3):1447-60. doi:10.1128/JVI.01225-13

90. De Clercq E. Antiviral agents active against influenza A viruses. Nat Rev Drug Discov (2006) 5(12):1015-25. doi:10.1038/nrd2175

91. Tutykhina IL, Sedova ES, Gribova IY, Ivanova TI, Vasilev LA, Rutovskaya MV, et al. Passive immunization with a recombinant adenovirus expressing an HA (H5)-specific single-domain antibody protects mice from lethal influenza infection. Antiviral Res (2013) 97(3):318-28. doi:10.1016/j. antiviral.2012.12.021

92. Pinto LH, Holsinger LJ, Lamb RA. Influenza-virus M2 protein has ion channel activity. Cell (1992) 69(3):517-28. doi:10.1016/0092-8674(92)90452-I

93. Palese P, Shaw ML. Orthomyxoviridae: the viruses and their replication. In: Ed Knipe DM, Howley PM, Griffin DE, Lamb RA, Martin MA, Roizman B, et al., editors. Fields Virology. Philadelphia, PA: Lippincott Williams \& Wilkins (2007) 1647-89.

94. Nair H, Nokes DJ, Gessner BD, Dherani M, Madhi SA, Singleton RJ, et al. Global burden of acute lower respiratory infections due to respiratory syncytial virus in young children: a systematic review and meta-analysis. Lancet (2010) 375(9725):1545-55. doi:10.1016/S0140-6736(10)60206-1

95. Battles MB, Langedijk JP, Furmanova-Hollenstein P, Chaiwatpongsakorn S, Costello HM, Kwanten L, et al. Molecular mechanism of respiratory syncytial virus fusion inhibitors. Nat Chem Biol (2016) 12(2):87-93. doi:10.1038/ nchembio. 1982

96. Johnson S, Oliver C, Prince GA, Hemming VG, Pfarr DS, Wang SC, et al. Development of a humanized monoclonal antibody (MEDI-493) with potent in vitro and in vivo activity against respiratory syncytial virus. J Infect Dis (1997) 176(5):1215-24. doi:10.1086/514115

97. Group TI-RS. Palivizumab, a humanized respiratory syncytial virus monoclonal antibody, reduces hospitalization from respiratory syncytial virus infection in high-risk infants. Pediatrics (1998) 102(3):531-7. doi:10.1542/ peds.102.3.531

98. Corti D, Bianchi S, Vanzetta F, Minola A, Perez L, Agatic G, et al. Crossneutralization of four paramyxoviruses by a human monoclonal antibody. Nature (2013) 501(7467):439-43. doi:10.1038/nature12442

99. Zhao M, Zheng ZZ, Chen M, Modjarrad K, Zhang W, Zhan LT, et al. Discovery of a prefusion respiratory syncytial virus F-specific monoclonal antibody that provides greater in vivo protection than the murine precursor of palivizumab. J Virol (2017) 91(15):e176-117. doi:10.1128/JVI.00176-17

100. Capella C, Chaiwatpongsakorn S, Gorrell E, Risch ZA, Ye F, Mertz SE, et al. Prefusion F, postfusion F, G antibodies and disease severity in infants and young children with acute respiratory syncytial virus infection. J Infect Dis (2017). doi:10.1093/infdis/jix489

101. Gentile I, Maraolo AE, Buonomo AR, Zappulo E, Borgia G. The discovery of sofosbuvir: a revolution for therapy of chronic hepatitis C. Expert Opin Drug Discov (2015) 10(12):1363-77. doi:10.1517/17460441.2015.1094051
102. Khan AG, Whidby J, Miller MT, Scarborough H, Zatorski AV, Cygan A, et al. Structure of the core ectodomain of the hepatitis $\mathrm{C}$ virus envelope glycoprotein 2. Nature (2014) 509(7500):381-4. doi:10.1038/nature13117

103. Law M, Maruyama T, Lewis J, Giang E, Tarr AW, Stamataki Z, et al. Broadly neutralizing antibodies protect against hepatitis $\mathrm{C}$ virus quasispecies challenge. Nat Med (2008) 14(1):25-7. doi:10.1038/nm1698

104. Morin TJ, Broering TJ, Leav BA, Blair BM, Rowley KJ, Boucher EN, et al. Human monoclonal antibody HCV1 effectively prevents and treats HCV infection in chimpanzees. PLoS Pathog (2012) 8(8):e1002895. doi:10.1371/ journal.ppat.1002895

105. Chung RT, Gordon FD, Curry MP, Schiano TD, Emre S, Corey K, et al. Human monoclonal antibody MBL-HCV1 delays HCV viral rebound following liver transplantation: a randomized controlled study. Am J Transplant (2013) 13(4):1047-54. doi:10.1111/ajt.12083

106. Looker KJ, Gamett GP, Schmid GP. An estimate of the global prevalence and incidence of herpes simplex virus type 2 infection. Bull World Health Organ (2008) 86(10):805-12. doi:10.2471/BLT.07.046128

107. Holmberg SD, Stewart JA, Gerber AR, Byers RH, Lee FK, Omalley PM, et al. Prior herpes-simplex virus type- 2 infection as a risk factor for HIV infection. J Am Med Assoc (1988) 259(7):1048-50. doi:10.1001/Jama.259.7.1048

108. Atanasiu D, Saw WT, Cohen GH, Eisenberg RJ. Cascade of events governing cell-cell fusion induced by herpes simplex virus glycoproteins $\mathrm{gD}, \mathrm{gH} / \mathrm{gL}$, and gB. J Virol (2010) 84(23):12292-9. doi:10.1128/JVI.01700-10

109. Nicola AV, Ponce de Leon M, Xu R, Hou W, Whitbeck JC, Krummenacher C, et al. Monoclonal antibodies to distinct sites on herpes simplex virus (HSV) glycoprotein D block HSV binding to HVEM. J Virol (1998) 72(5):3595-601.

110. Pant N, Hultberg A, Zhao Y, Svensson L, Pan-Hammarstrom Q, Johansen K, et al. Lactobacilli expressing variable domain of llama heavy-chain antibody fragments (lactobodies) confer protection against rotavirus-induced diarrhea. J Infect Dis (2006) 194(11):1580-8. doi:10.1086/508747

111. Pant N, Marcotte H, Hermans P, Bezemer S, Frenken L, Johansen K, et al. Lactobacilli producing bispecific llama-derived anti-rotavirus proteins in vivo for rotavirus-induced diarrhea. Future Microbiol (2011) 6(5):583-93. doi: $10.2217 / \mathrm{fmb} .11 .32$

112. Sarker SA, Jakel M, Sultana S, Alam NH, Bardhan PK, Chisti MJ, et al Anti-rotavirus protein reduces stool output in infants with diarrhea: a randomized placebo-controlled trial. Gastroenterology (2013) 145(4):740-8. e8. doi:10.1053/.j.gastro.2013.06.053

113. Hansman GS, Natori K, Shirato-Horikoshi H, Ogawa S, Oka T, Katayama K, et al. Genetic and antigenic diversity among noroviruses. J Gen Virol (2006) 87(Pt 4):909-19. doi:10.1099/vir.0.81532-0

114. Hansman GS, Taylor DW, McLellan JS, Smith TJ, Georgiev I, Tame JR, et al. Structural basis for broad detection of genogroup II noroviruses by a monoclonal antibody that binds to a site occluded in the viral particle. J Virol (2012) 86(7):3635-46. doi:10.1128/JVI.06868-11

115. Shiota T, Okame M, Takanashi S, Khamrin P, Takagi M, Satou K, et al. Characterization of a broadly reactive monoclonal antibody against norovirus genogroups I and II: recognition of a novel conformational epitope. J Virol (2007) 81(22):12298-306. doi:10.1128/JVI.00891-07

116. Ryckaert S, Pardon E, Steyaert J, Callewaert N. Isolation of antigen-binding camelid heavy chain antibody fragments (nanobodies) from an immune library displayed on the surface of Pichia pastoris. J Biotechnol (2010) 145(2):93-8. doi:10.1016/j.jbiotec.2009.10.010

117. Ying T, Chen W, Feng Y, Wang Y, Gong R, Dimitrov DS. Engineered soluble monomeric IgG1 CH3 domain: generation, mechanisms of function, and implications for design of biological therapeutics. J Biol Chem (2013) 288(35):25154-64. doi:10.1074/jbc.M113.484154

118. Ying T, Ju TW, Wang Y, Prabakaran P, Dimitrov DS. Interactions of IgG1 $\mathrm{CH} 2$ and $\mathrm{CH} 3$ domains with FcRn. Front Immunol (2014) 5:146. doi:10.3389/ fimmu.2014.00146

119. Ying T, Wang Y, Feng Y, Prabakaran P, Gong R, Wang L, et al. Engineered antibody domains with significantly increased transcytosis and half-life in macaques mediated by FcRn. MAbs (2015) 7(5):922-30. doi:10.1080/1942 0862.2015.1067353

120. Ying T, Feng Y, Wang Y, Chen W, Dimitrov DS. Monomeric IgG1 Fc molecules displaying unique $\mathrm{Fc}$ receptor interactions that are exploitable to treat inflammation-mediated diseases. MAbs (2014) 6(5):1201-10. doi:10.4161/ mabs. 29835 
121. Wang L, Ying T. New directions for half-life extension of protein therapeutics: the rise of antibody Fc domains and fragments. Curr Pharm Biotechnol (2016) 17(15):1348-52. doi:10.2174/1389201017666160823144032

122. Jespers L, Schon O, James LC, Veprintsev D, Winter G. Crystal structure of HEL4, a soluble, refoldable human VH single domain with a germ-line scaffold. J Mol Biol (2004) 337(4):893-903. doi:10.1016/j.jmb.2004.02.013

123. Dudgeon K, Rouet R, Kokmeijer I, Schofield P, Stolp J, Langley D, et al. General strategy for the generation of human antibody variable domains with increased aggregation resistance. Proc Natl Acad Sci U S A (2012) 109(27):10879-84. doi:10.1073/pnas.1202866109
Conflict of Interest Statement: The authors declare that the article content was composed in the absence of any commercial or financial relationships that could be construed as a potential conflict of interest.

Copyright $\odot 2017 \mathrm{Wu}$, Jiang and Ying. This is an open-access article distributed under the terms of the Creative Commons Attribution License (CC BY). The use, distribution or reproduction in other forums is permitted, provided the original author(s) or licensor are credited and that the original publication in this journal is cited, in accordance with accepted academic practice. No use, distribution or reproduction is permitted which does not comply with these terms. 